This is a postprint version of the following published document:

Sierra-Fernández, A., Gómez-Villalba, L.S., Milosevic, O., Fort, R., Rabanal, M.E. (2014). Synthesis and morpho-structural characterization of nanostructured magnesium hydroxide obtained by a hydrothermal method. Ceramics International, vol. 40, n. 8, Part A, pp. 12285-12292. Doi: https://doi.org/10.1016/j.ceramint.2014.04.073

(c) 2014 Elsevier Ltd and Techna Group S.r.l. All rights reserved

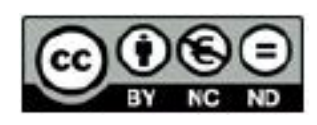

This work is licensed under a Creative Commons Attribution-NonCommercialNoDerivatives 4.0 International License. 


\title{
Synthesis and morpho-structural characterization of nanostructured magnesium hydroxide obtained by a hydrothermal method
}

\author{
A. Sierra Fernandez ${ }^{\mathrm{a}, \mathrm{b}, *}$, L.S. Gomez Villalba ${ }^{\mathrm{a}}$, O. Milosevic ${ }^{\mathrm{c}}$, R. Fort ${ }^{\mathrm{a}}$, M.E. Rabanal ${ }^{\mathrm{b}}$ \\ ${ }^{\mathrm{a}}$ Instituto de Geociencias (CSIC,UCM), C/ José Antonio Novais 2, CP 28040, Spain \\ ${ }^{\mathrm{b}}$ University Carlos III of Madrid and IAAB, Department of Materials Science and Engineering and Chemical Engineering, Avda. Universidad 30, \\ 28911 Leganes, Madrid, Spain \\ ${ }^{\mathrm{c}}$ Institute of Technical Sciences of the Serbian Academy of Sciences and Arts, Knez Mihailova 35/IV, 11000 Belgrade, Serbia
}

\begin{abstract}
Controlled magnesium hydroxide particles were successfully synthesized via a simple hydrothermal method. The influence of temperature and reaction time on the hydrothermal synthesis of $\mathrm{Mg}(\mathrm{OH})_{2}$ was studied. The results provide new parameters to control the morphologies, particle sizes, agglomeration level and crystallographic structures of the brucite nanosized. The physic chemical properties of synthesized $\mathrm{Mg}(\mathrm{OH})_{2}$ nanoparticles have been characterized by X ray diffraction (XRD), scanning electron microscopy (SEM), transmission electron microscopy (TEM) combined with selected area electron diffraction (SAED), high resolution transmission electron microscopy (HR TEM) and thermogravimetry/ differential scanning calorimetry (TG/DSC). It has been shown that the prolongation of reaction time improves the crystalline degree of magnesium hydroxide particles. It was also possible to detect a relevant increase in the degree of crystallinity and a faster crystal growth with defined hexagonal morphologies in the samples obtained at higher temperature. Our results show that this simple hydrothermal route is highly interesting for the large scale production of these nanomaterials.
\end{abstract}

(c) 2014 Elsevier Ltd and Techna Group S.r.l. All rights reserved.

Keywords: Brucite; Crystallization; Hydrothermal treatment; $\mathrm{Mg}(\mathrm{OH})_{2}$; Nanocrystals

\section{Introduction}

Recently, interest in magnesium hydroxide $\left(\mathrm{Mg}(\mathrm{OH})_{2}\right)$ nanoparticles has been increasing rapidly due to the fact that these nanoparticles have multiple applications in medicine [1], industry [2] and more recently, in the conservation of cultural heritage $[3,4]$. The reason why the nanoparticles have multiple applications is that crystalline $\mathrm{Mg}(\mathrm{OH})_{2}$ offers several great advantages, such as a good thermal stability, good fire retardant properties, a low toxicity and a low cost $[5,6]$. In addition, the $\mathrm{Mg}(\mathrm{OH})_{2}$ nanoparticles may be effective antibacterial agents $[7,8]$. Therefore, magnesium hydroxide is commonly used in different products providing them important properties. The incorporation of $\operatorname{Mg}(\mathrm{OH})_{2}$ into polymers due to its flame retardancy has received special attention because brucite can improve properties of composites and extend their applications [9,10]. Recently, Ma et al. have successfully assembled magnesium hydroxide nanoparticles on the surface of cotton fibers in order to improve the flammability and stability of these composites [11]. These types of nanoparticles are also used in the deacidification treatment of paper, this being an efficient method to inhibit the degradation of old paper [12]. It has also been found that magnesium hydroxide exhibits promising $\mathrm{CO}_{2}$ adsorption properties due to its mineral carbonation process [13]. Furthermore, $\operatorname{Mg}(\mathrm{OH})_{2}$ is one of the most important precursors of magnesium oxide $(\mathrm{MgO})$ [14], a versatile metal oxide that is used in multiple applications and products with important mechanical, catalytic and electronic properties $[15,16]$.

It is essential to take into account that the method used for obtaining the nanoparticles is a decisive factor to enhance 
the suitability of these nanomaterials. The conditions of the process need to be controlled in order to obtain nanocrystals with certain morphologies, particle sizes, agglomeration level and crystallographic structures. Therefore, the controlled preparation of nano-structured magnesium hydroxide has been the focus of many studies. Various chemical routes have been used to synthesize $\mathrm{Mg}(\mathrm{OH})_{2}$ nanocrystals with different morphologies and structures. Fan et al. have obtained $\mathrm{Mg}(\mathrm{OH})_{2}$ in one-dimensional form also known as nanotubes through a solvothermal method, using $\mathrm{Mg}_{10}(\mathrm{OH})_{18} \mathrm{Cl}_{2} \cdot 5 \mathrm{H}_{2} \mathrm{O}$ as precursor without any surfactant or catalyst $[17,18]$. Most recently, $\mathrm{Li}$ et al. prepared hexagonal nanoplates $\mathrm{Mg}(\mathrm{OH})_{2}$ by a bubbling method in the presence of gelatin and polyvinyl alcohol as high molecular surfactants [19]. Another method of synthesis used lately for the magnesium hydroxide production is the microwave-assisted technique. Beall et al. used this technique for the production of pseudo-hexagonal $\mathrm{Mg}(\mathrm{OH})_{2}$ nanostructures [20]. The brucite nanoparticles may be prepared at room temperature as well. Das et al. have carried out the formation of $\mathrm{Mg}(\mathrm{OH})_{2}$ micro/nanoflowers under these conditions. The authors also identified the best conditions that favor the growth of magnesium hydroxide at room temperature [21]. Superfine magnesium hydroxide with monodispersity has been synthesized via a direct precipitation method at a reaction temperature of $25^{\circ} \mathrm{C}$ by Wu et al. [22]. A similar procedure was adopted by Yan et al., who got superfine arrays of magnesium hydroxide nanoparticles synthesized via the direct precipitation method at room temperature through the addition of a cationic surfactant, cetyl trimethyl ammonium bromide (CTAB) [23]. On the other hand, magnesium hydroxide nanocrystals can also be obtained by hydration of magnesium oxide, $\mathrm{MgO}[24,25]$. Qian et al. obtained platelet-shaped particles using the hydrating method of $\mathrm{MgO}$, made from the decomposition of magnesite [26]. The precipitation of a magnesium salt with an alkaline solution is another synthesis method that has been employed for obtaining brucite nanoparticles with different morphologies as globular agglomerates, platelet-shaped particles or hexagonal lamellas [27,28]. Song et al. synthesized magnesium hydroxide nanoparticles with lamellar structure via one-step precipitation reaction with the aid of ultrasonic treatment [29].

The hydrothermal synthesis method is one of the most widely employed techniques for the synthesis of brucite nanostructures with the ease of large-scale production [30]. A large number of studies have shown that this synthesis method is an effective way to control the morphology, particle size distribution and phase homogeneity [31,32]. In a recent work, Jin et al. [33] prepared $\mathrm{Mg}(\mathrm{OH})_{2}$ nanoparticles by hydrothermal method using magnesium nitrate $\left(\mathrm{Mg}\left(\mathrm{NO}_{3}\right)_{2}\right)$ and hydrazine hydrate $\left(\mathrm{N}_{2} \mathrm{H}_{4} \cdot \mathrm{H}_{2} \mathrm{O}\right)$ without further additives. In our belief, studying the influence of experimental synthesis parameters on the morphologies, the particle sizes, the agglomeration level and the crystallographic structures of the particles obtained is of special interest. Thus, in this paper, the effect of synthesis temperature and reaction time on the hydrothermal treatment of nanocrystalline $\operatorname{Mg}(\mathrm{OH})_{2}$, using hydrazine hydrate $\left(\mathrm{N}_{2} \mathrm{H}_{4} \cdot \mathrm{H}_{2} \mathrm{O}\right)$ as precipitator, has been tried for the first time. We report the preparation and characterization of $\mathrm{Mg}(\mathrm{OH})_{2}$ nanostructures with different morphologies, particle sizes, high purity and preferred orientation. These results may contribute not only for defining the structures and making morphologies more favorable but also to make the large-scale production of these nanomaterials possible.

\section{Experimental section}

\subsection{Materials}

All the chemical reagents used in this work, magnesium nitrate hexahydrate $\left(\mathrm{Mg}\left(\mathrm{NO}_{3}\right)_{2} \cdot 6 \mathrm{H}_{2} \mathrm{O}\right)$ and hydrazine hydrate $\left(\mathrm{N}_{2} \mathrm{H}_{4} \cdot \mathrm{H}_{2} \mathrm{O}\right)$, were purchased from Sigma-Aldrich and used as received, without further purification. High-purity water $(18 \mathrm{M} \Omega / \mathrm{cm})$ was prepared by a deionized water purification system (Barnstead, Dubuque, IA, USA) and was used in all procedures.

\subsection{Synthesis of magnesium hydroxide nanoparticles}

Magnesium hydroxide nanoparticles were synthesized via the hydrothermal method using $\mathrm{Mg}\left(\mathrm{NO}_{3}\right)_{2} \cdot 6 \mathrm{H}_{2} \mathrm{O}$ as a magnesium precursor and $\mathrm{N}_{2} \mathrm{H}_{4} \cdot \mathrm{H}_{2} \mathrm{O}$ as a precipitator. It has conducted different reaction parameters in order to evaluate the influence of the synthesis temperature and the reaction time in the nanoparticles obtained. These reaction conditions are summarized in Table 1. For a typical preparation process, $0.12 \mathrm{~g} \mathrm{Mg}\left(\mathrm{NO}_{3}\right)_{2} \cdot 6 \mathrm{H}_{2} \mathrm{O}$ was dissolved in $10 \mathrm{ml}$ high-purity water. Subsequently, $0.08 \mathrm{ml}$ of $\mathrm{N}_{2} \mathrm{H}_{4} \cdot \mathrm{H}_{2} \mathrm{O}$ was added into $\mathrm{Mg}\left(\mathrm{NO}_{3}\right)_{2}$ solution dropwise and made up to $15 \mathrm{ml}$ with water. The resulting mixture was vigorously stirred at room temperature until a white uniform suspension appeared. Finally, the obtained suspension was then transferred into a Teflon-lined stainless steel autoclave, sealed and hydrothermally treated at a constant reaction temperature in the range of $150180{ }^{\circ} \mathrm{C}$ for 24, 12 and $6 \mathrm{~h}$. The obtained mixtures were cooled at room temperature and then separated in a centrifuge; a wash was implemented several times using distilled water in order to remove the residual impurities, followed by a wash with

Table 1

Synthesis conditions of $\mathrm{Mg}(\mathrm{OH})_{2}$ nanoparticles obtained at precursor quantity of $\mathrm{Mg}\left(\mathrm{NO}_{3}\right)_{2} \cdot 6 \mathrm{H}_{2} \mathrm{O}$ of $0.12 \mathrm{~g}$ and $0.08 \mathrm{ml}$ of $\mathrm{N}_{2} \mathrm{H}_{4} \cdot \mathrm{H}_{2} \mathrm{O}$; and variation of crystallite sizes determined from XRD.

\begin{tabular}{|c|c|c|c|c|c|c|}
\hline \multirow[t]{2}{*}{ Sample } & \multirow[t]{2}{*}{$\begin{array}{l}\text { Reaction } \\
\text { temperature } \\
\left({ }^{\circ} \mathrm{C}\right)\end{array}$} & \multirow[t]{2}{*}{$\begin{array}{l}\text { Reaction } \\
\text { time (h) }\end{array}$} & \multirow[t]{2}{*}{$\begin{array}{l}\text { Particle } \\
\text { size }(\mathbf{n m})^{\mathrm{a}}\end{array}$} & \multirow[t]{2}{*}{$\begin{array}{l}\text { Crystallite } \\
\text { size }(\mathbf{n m})^{\mathrm{b}}\end{array}$} & \multicolumn{2}{|c|}{$\begin{array}{l}\text { Unit cell } \\
\text { dimensions } \\
(\AA)\end{array}$} \\
\hline & & & & & $a$ & $c$ \\
\hline I & 150 & 24 & $127 \pm 34$ & $36 \pm 4$ & 3.19 & 4.72 \\
\hline II & 150 & 12 & $75 \pm 55$ & $42 \pm 4$ & 3.12 & 4.73 \\
\hline III & 180 & 12 & $163 \pm 45$ & $43 \pm 4$ & 3.13 & 4.74 \\
\hline IV & 180 & 6 & $456 \pm 53$ & $45 \pm 4$ & 3.13 & 4.74 \\
\hline
\end{tabular}

${ }^{a}$ Results determined from TEM images.

${ }^{\mathrm{b}}$ Results obtained by the Scherrer's formula $(D=K \lambda / \beta \cos \theta)$ and derived from the most intense indexed peaks, (001) and (101). 
ethanol, used for reducing the agglomeration. Finally, the samples obtained were dried in an inert gas atmosphere at $60{ }^{\circ} \mathrm{C}$ for $7 \mathrm{~h}$ yielding a white nanosized brucite powder.

\subsection{Characterization}

The phase purity and crystallographic structures of the magnesium hydroxide nanoparticles obtained were examined by the X-ray diffraction (XRD) (Philips X'Pert) operating at $40 \mathrm{kV}$ and $40 \mathrm{~mA}$ and employing $\mathrm{Cu} \mathrm{K} \alpha$ radiation $(\lambda=1.54 \AA)$. The average crystallite size (CS) of the $\mathrm{Mg}(\mathrm{OH})_{2}$ nanoparticles was determined by the Scherrer's formula, $D=K \lambda / \beta \cos \theta$, where $\lambda$ is the wavelength of the X-ray radiation (in $\AA$ ), $K$ is a constant taken as $0.9, \beta$ the full width at half-maximum height (FWHM) and $\theta$ is the diffraction angle (in rad) used in calculus [34]. The two most intensive reflection peaks of the samples were used in the line broadening analysis. The morphological study and chemical composition of the samples were conducted by scanning electron microscopy (SEM) (Philips XL 30/EDS D $\times 4$ ) and transmission electron microscopy (TEM) selected area electron diffraction (SAED) (JEOL JEM 2100 at $200 \mathrm{kV}$ ). SEM images were obtained with the surface of the samples coated with a thin gold layer to avoid a charging effect. The samples for TEM studies were ultrasonically dispersed in acetone and then deposited on holey carbon copper grids. HRTEM was carried out in conjunction with fast Fourier transformed (FFT) using a JEOL JEM $3000 \mathrm{~F}$ transmission electron microscope at $300 \mathrm{kV}$ operating voltage. The distribution and average size of the nanostructures obtained were determined from TEM images using the Digital Micrograph $^{\mathrm{TM}}$ (DM, Gatan Inc.) software. The dimensions and the standard deviations of 15 nanoparticles randomly chosen in each sample were measured.

Thermal stability evaluation of the magnesium hydroxide nanoparticles obtained were carried out using a TGA, DSC Perkin-Elmer STA 6000 simultaneous thermal analyzer under nitrogen atmosphere (flow rate $20 \mathrm{~mL} / \mathrm{min}$ ) from 25 to $600{ }^{\circ} \mathrm{C}$ with a continuous heating rate of $10{ }^{\circ} \mathrm{C} \mathrm{min}^{-1}$.

\section{Results and discussion}

The crystal phases and crystallinity of the nanosized $\mathrm{Mg}(\mathrm{OH})_{2}$ obtained were determined by X-ray diffraction. Fig. 1 shows the $\mathrm{X}$-ray diffraction (XRD) patterns of the as-prepared samples I, II, III and IV obtained by the hydrothermal method at different synthesis temperatures $\left(150\right.$ and $\left.180{ }^{\circ} \mathrm{C}\right)$ and reaction times $(24$, 12 and $6 \mathrm{~h}$ ). These XRD patterns exhibited typical diffraction peaks which were assigned to (001), (100), (101), (102) and (110) planes of the structure of $\mathrm{Mg}(\mathrm{OH})_{2}$ (Joint Committee on Powder Diffraction Standards File (JCPDS) no. 44-1482, space group $P-3 m 1$ with unit cell parameters $a=3.144 \AA$ and $c=4.777 \AA$ ). No additional XRD peaks arising from impurities were detected. However, it is important to point out that the relative intensities of some peaks do not agree with the standard X-ray diffraction powder pattern of the brucite. Thus, the intensity of $\mathrm{Mg}(\mathrm{OH})_{2}$ (001) plane's peak, which corresponds to the basal plane of brucite, is stronger than the diffraction peak for the (101) plane. These differences in diffraction intensities could be caused by the

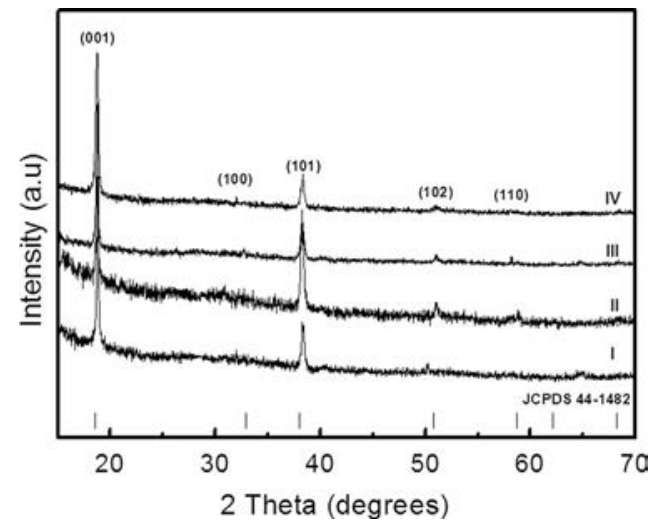

Fig. 1. XRD patterns of $\mathrm{Mg}(\mathrm{OH})_{2}$ nanoparticles obtained at various synthesis conditions: (I) $150{ }^{\circ} \mathrm{C}, 24 \mathrm{~h}$; (II) $150{ }^{\circ} \mathrm{C}, 12 \mathrm{~h}$; (III) $180{ }^{\circ} \mathrm{C}, 12 \mathrm{~h}$ and (IV) $180{ }^{\circ} \mathrm{C}, 6 \mathrm{~h}$. All major peaks could be indexed to the hexagonal structure of the $\mathrm{Mg}(\mathrm{OH})_{2}$ (JCPDS 44 1482)

Table 2

TGA DSC results for the thermal decomposition of the $\mathrm{Mg}(\mathrm{OH})_{2}$ nanoparti cles obtained at different synthesis conditions.

\begin{tabular}{|c|c|c|c|c|c|c|}
\hline \multirow[t]{2}{*}{ Sample } & \multicolumn{3}{|l|}{ TGA } & \multicolumn{3}{|l|}{ DSC } \\
\hline & $\begin{array}{l}T \text { onset } \\
\left({ }^{\circ} \mathrm{C}\right)\end{array}$ & $\begin{array}{l}T \text { offset } \\
\left({ }^{\circ} \mathbf{C}\right)\end{array}$ & $\begin{array}{l}\text { Weight loss } \\
\text { (wt\%) }\end{array}$ & $\begin{array}{l}T \text { onset } \\
\left({ }^{\circ} \mathbf{C}\right)\end{array}$ & $\begin{array}{l}T \text { offset } \\
\left({ }^{\circ} \mathbf{C}\right)\end{array}$ & $\begin{array}{l}T \text { peak } \\
\left({ }^{\circ} \mathbf{C}\right)\end{array}$ \\
\hline I & 300.4 & 394.3 & 28.5 & 333.1 & 391.2 & 372.3 \\
\hline II & 355.4 & 370.9 & 31.4 & 323.9 & 380.8 & 366.1 \\
\hline III & 305.2 & 382.2 & 29.8 & 334.4 & 401.1 & 378.5 \\
\hline IV & 321.3 & 391.02 & 29 & 359.8 & 398.2 & 386.1 \\
\hline
\end{tabular}

preferred growth orientation of the brucite crystals according to the experimental conditions in the synthesis [35,36]. Lv et al. [37] suggest that the concentration ratio of hydroxyl ion and magnesium ion is the key factor that causes the preferred orientation. According to $\mathrm{Wu}$ et al. [35] the (001) plane of $\mathrm{Mg}(\mathrm{OH})_{2}$ is nonpolar while the (101) plane is polar. These authors studied the influence of $\mathrm{CaCl}_{2}$ on the hydrothermal modification of $\mathrm{Mg}(\mathrm{OH})_{2}$ and they reported that the weakening of the polarity of brucite after hydrothermal treatment was favorable for its dispersion. In addition, due to the fact that the crystal face (001) diffraction is the highest, it would produce a more stable structure of magnesium hydroxide due to the decrease in polarity [38]. Moreover, the strong and sharp diffraction peaks suggested that the $\operatorname{Mg}(\mathrm{OH})_{2}$ nanoparticles were highly crystallized, which was consistent with the TEM results. It was also possible to detect a significant increase of the crystallinity degree and a faster crystal growth in the samples obtained at $180{ }^{\circ} \mathrm{C}$ which reveals that the crystallization of the brucite nanoparticles could be improved at higher temperatures [19,39]. The $\mathrm{Mg}(\mathrm{OH})_{2}$ crystallite size could be estimated from XRD patterns using the Scherrer's formula. The results derived from the most intense indexed peaks, (001) and (101), are listed in Table 2. It was found that the estimated crystallite sizes for the $\mathrm{Mg}(\mathrm{OH})_{2}$ samples obtained in this study were in the range $3042 \mathrm{~nm}$. As it can be seen, the highest value of the average crystallite size was obtained 
for sample II. This may be caused by the strong aggregation of particles observed by SEM and TEM, which would lead to larger nanoparticles composed of several crystallites.

Scanning electron microscopy (SEM) revealed the existence of important differences in the morphologies and particle sizes of the magnesium hydroxide nanoparticles obtained according to the synthesis parameters studied. Fig. 2 shows SEM micrographs of $\mathrm{Mg}(\mathrm{OH})_{2}$ particles obtained. From Fig. 2a, a reaction time of $24 \mathrm{~h}$ at $150{ }^{\circ} \mathrm{C}$ resulted in the formation of hexagonal flakes with rounded edges in sample I. The mean of the longer side was about $\sim 120 \pm 30 \mathrm{~nm}$ and the thickness was $\sim 15 \mathrm{~nm}$. It is interesting to note that when the reaction time decreased from 24 to $12 \mathrm{~h}$, the morphology, the size particle and the agglomeration level observed in sample II were clearly different from the previous one (Fig. 2b). Thus, in this sample, more inhomogeneous particles were formed due to the insufficient time given to the particles to grow. Furthermore, sample II presented a strong tendency to form agglomerates. Even though this aggregation feature did not allow an accurate measurement of the particle size, the grain boundaries observed indicated that the longer side of nanoparticles of these aggregates lies within $\sim 70 \pm 30 \mathrm{~nm}$. This agglomeration phenomenon was caused by their high surface energy which is the result of the small particle size. However, Fig. 2c shows for sample III (treated at $180{ }^{\circ} \mathrm{C}$ for $12 \mathrm{~h}$ ) that the increase of temperature from $150{ }^{\circ} \mathrm{C}$ to $180{ }^{\circ} \mathrm{C}$ led to the formation of well-defined hexagonal nanoplates of magnesium hydroxide, with a bigger uniform size of $\sim 160 \pm 40 \mathrm{~nm}$ and a thickness of $\sim 18 \mathrm{~nm}$. This formation of bigger particles confirmed that the hydrothermal modification may be carried out through the dissolution of the agglomerated particles and the precipitation when the supersaturated concentration at the hydrothermal condition is reached. As we can see in Fig. 2d, it was especially interesting to find particular arrangement morphologies in sample IV due to the regular intergrowth of crystals at this time reaction. Majority of particles produced at these conditions have average sizes of around $\sim 450 \pm 50 \mathrm{~nm}$ and thicknesses of $\sim 28 \mathrm{~nm}$.

Morphological and crystallographic differences of the $\mathrm{Mg}(\mathrm{OH})_{2}$ particles obtained were observed by transmission electron microscopy (TEM), combined with selected area electron diffraction (SAED) and high-resolution transmission electron microscopy (HRTEM). These data were correlated with the previous results obtained from XRD and SEM studies. Fig. 3 shows the lowmagnification TEM images and the corresponding SAED patterns of the $\mathrm{Mg}(\mathrm{OH})_{2}$ particles obtained at the synthesis reaction time of $12 \mathrm{~h}$ at $150{ }^{\circ} \mathrm{C}$ and $180^{\circ} \mathrm{C}$. It can be seen that these brucite samples showed relevant differences in the degree of aggregation,
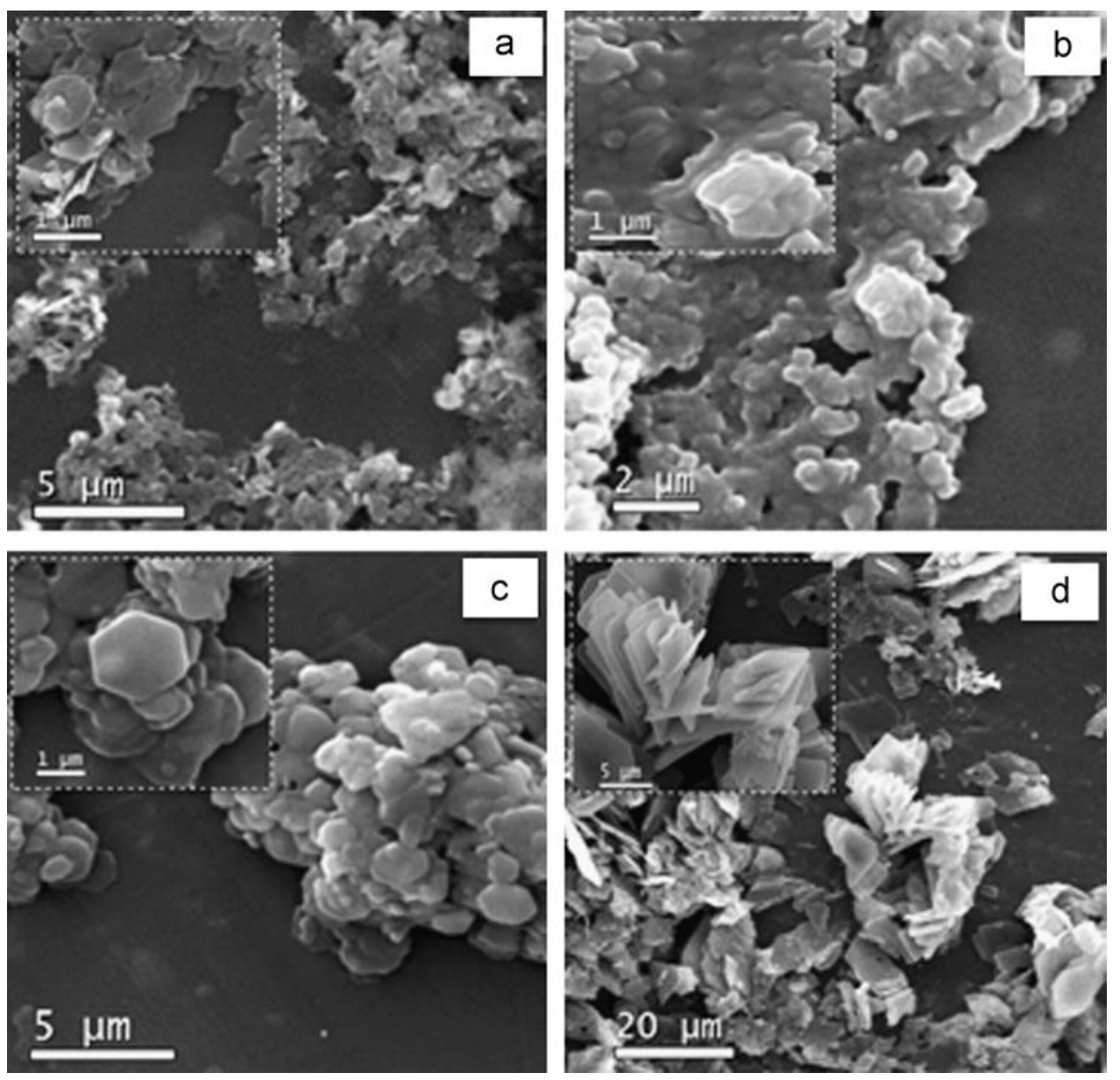

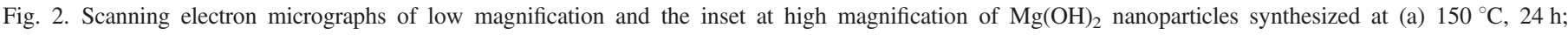
(b) $150{ }^{\circ} \mathrm{C}, 12 \mathrm{~h}$; (c) $180{ }^{\circ} \mathrm{C}, 12 \mathrm{~h}$ and (d) $180{ }^{\circ} \mathrm{C}, 6 \mathrm{~h}$ via a hydrothermal method. 

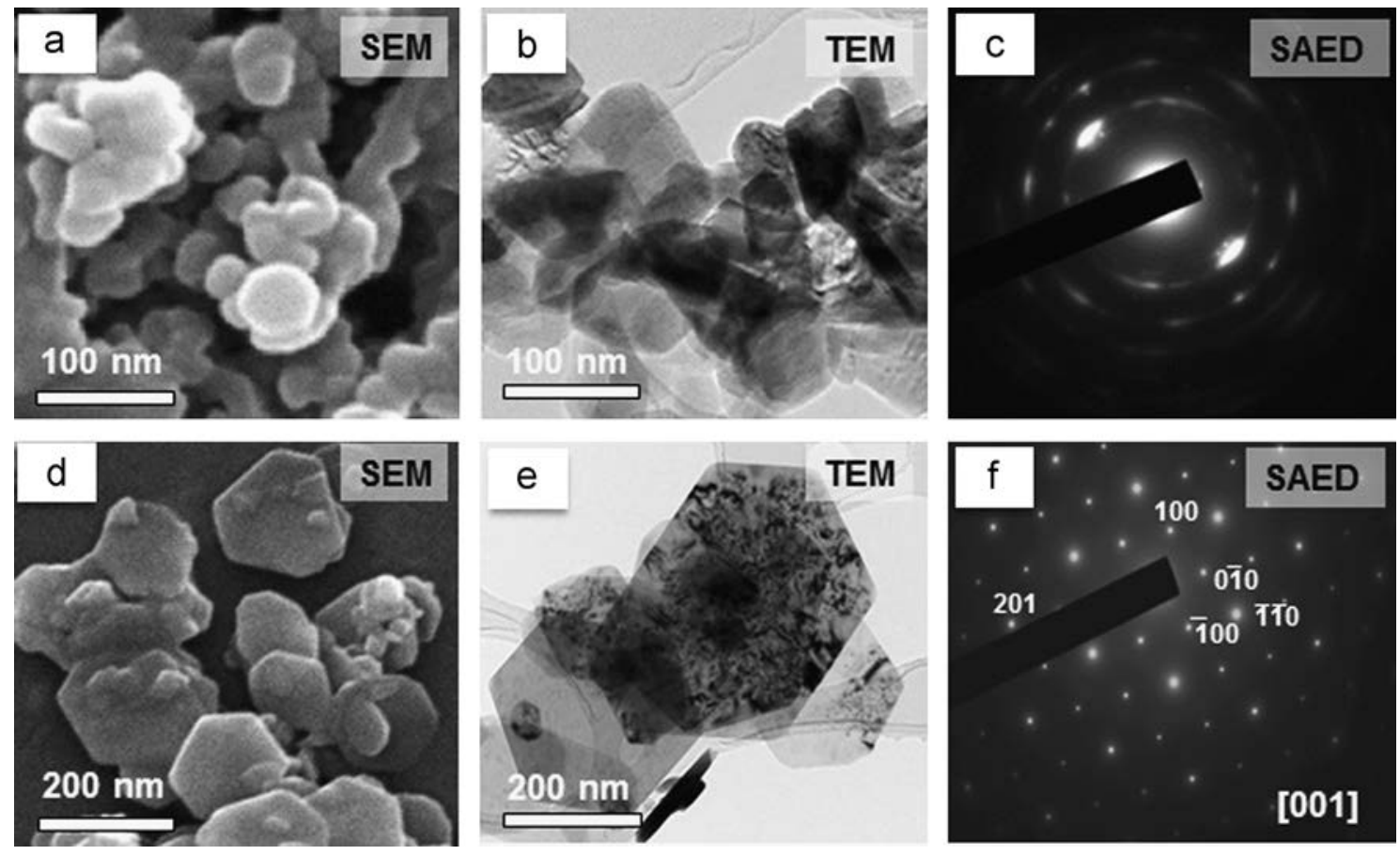

Fig. 3. Scanning electron micrographs (a, d), low magnification TEM images (b, e) and SAED patterns (c, f) for $\mathrm{Mg}(\mathrm{OH})_{2}$ nanoparticles obtained at $150{ }^{\circ} \mathrm{C}$ for $12 \mathrm{~h}$ (a c) and at $180{ }^{\circ} \mathrm{C}$ for $12 \mathrm{~h} \mathrm{(d} \mathrm{f).}$

habit and particle size. According to this, at the lower synthesis temperature $\left(150^{\circ} \mathrm{C}\right)$, irregular flakes of brucite with hexagonal habit and high level of agglomeration $(\sim 40100 \mathrm{~nm})$ were observed (Fig. 3b). Conversely, the $\mathrm{Mg}(\mathrm{OH})_{2}$ particles synthesized at temperature of $180{ }^{\circ} \mathrm{C}$ showed more regular shapes and larger particle sizes in the range of $\sim 150260 \mathrm{~nm}$ (Fig. 3e). This increasing trend of the particle sizes with the increase in temperature was observed by Chen et al. [39]; in addition, the SAED patterns also showed differences. An important improvement in the crystallinity was clearly seen in the $\mathrm{Mg}(\mathrm{OH})_{2}$ nanostructures obtained at $180^{\circ} \mathrm{C}$ as can be seen in the SAED pattern obtained for sample III (Fig. 3f). In this way, while the SAED pattern observed for sample II (Fig. 3c) suggested its polycrystalline nature with structural defects due to the aggregation of fine particles, the pattern for sample III showed strong spots in regular positions indicating its single-crystalline nature. Thus, sample III showed a regular hexagonal symmetry, characteristic of the structure of the brucite. The well-defined points in the SAED pattern shown can be indexed to the reflections of a hexagonal $\mathrm{Mg}$ $(\mathrm{OH})_{2}$ crystal according to the theoretical model of the brucite structure oriented along [0001]. The HR-TEM study shows that the nanosized $\operatorname{Mg}(\mathrm{OH})_{2}$ are not stable under the exposition to the high energy electron beam, $300 \mathrm{kV}$, of the TEM. The damage of the brucite nanosized in situ and in vacuo was observed as soon as the samples were exposed to the high energy electron beam. This fact is clearly shown in the low magnification TEM obtained for sample I (Fig. 4a) in which the degradation of the area of sample can be seen after the high-resolution study. The low stability of hydroxides under the high energy electron beam of the transmission electron microscopy has been reported by some authors
[40,41]. Fig. 4b and c shows the high-resolution electron microscopy (HRTEM) image obtained for sample I and the corresponding FFT pattern. It can be seen that the crystal shows variations in contrast that reveal the presence of porosity. Several authors [42 44] attributed these contrast changes to the onset of $\mathrm{Mg}(\mathrm{OH})_{2}$ decomposition and the loss of water under the electron beam. The crystal is composed of several nanocrystalline domains and the inter-planar distances observed are $1.49 \AA$ and $4.70 \AA$ which agree well with the lattice spacing of $\mathrm{Mg}(\mathrm{OH})_{2}$ (111) and (001) planes, respectively and $2.44 \AA$ which corresponds to the (111) crystal plane of periclase (MgO). Locally tiny cracks affect both the periclase and brucite domains. The optical diffraction pattern in Fig. 4c (as inset) corresponds to the [101]zone axis of $\mathrm{MgO}$, which presents diffuse spots along the (111) of the periclase phase, suggesting high content of defects; besides faint spots corresponding to the basal plane of brucite (001) are identified. According to Goodman [42] the conversion from $\mathrm{Mg}(\mathrm{OH})_{2}$ to $\mathrm{MgO}$, induced by transmission electron microscopy (TEM) is an inhomogeneous decomposition while other authors, as Ball et al. [43], proposed that this decomposition is homogeneous. These studies reported that the protons migrate to donor regions and the $\mathrm{Mg}^{2+}$ to acceptor regions. In this way, the acceptor regions in brucite are converted to periclase $(\mathrm{MgO})$ caused by the gain of cations and the donor regions are destroyed and become the pores. This formation of pores can be seen in the electron micrograph obtained (Fig. 4c), in which it is possible to see the formation of a pore with a longer side of about $\sim 1.2 \mathrm{~nm}$.

The study of the thermal behavior and stability of the magnesium hydroxide nanostructures obtained was carried out through TG DSC analyses. The results of these analyses are 

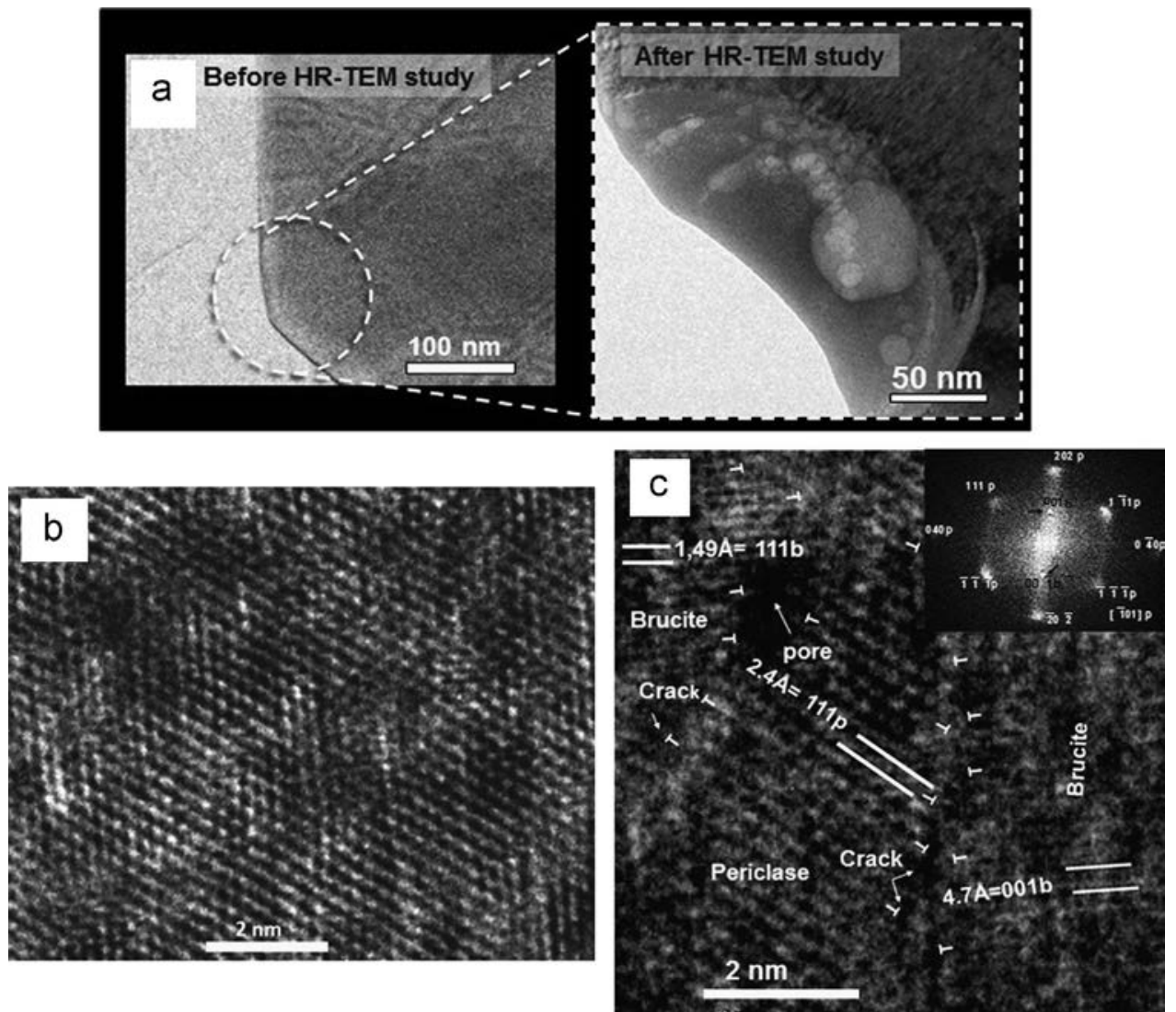

Fig. 4. Analytical TEM and HRTEM images of the $\mathrm{Mg}(\mathrm{OH})_{2}$ decomposition induced by transmission electron microscopy. (a) Low resolution TEM image of the $\mathrm{Mg}(\mathrm{OH})_{2}$ sample in which can be seen the damage of the sample from the electron beam. (b) High resolution TEM image of sample I that shows the general appearance of $\mathrm{Mg}(\mathrm{OH})_{2}$ (brucite) transformed into $\mathrm{MgO}$ (periclase). (c) Detailed HRTEM image of sample I revealing electron beam conversion to $\mathrm{MgO}$ as indicated by the fast Fourier transform (inset).

shown in Table 2. These results confirm a pronounced weight loss in all the brucite samples when the reaction temperature exceeds $300{ }^{\circ} \mathrm{C}$. These mass losses correspond to the thermal decomposition of dehydroxilation of magnesium hydroxide in magnesium oxide $\left(\mathrm{Mg}(\mathrm{OH})_{2(\mathrm{~s})} \rightarrow \mathrm{MgO}_{(\mathrm{s})}+\mathrm{H}_{2} \mathrm{O}_{(\mathrm{g})}\right)$. In addition, due to the thermal decomposition of dehydroxylation of $\mathrm{Mg}(\mathrm{OH})_{2}$ being an endothermic reaction, the DSC curve was expected to show an endothermic peak at temperatures over $300{ }^{\circ} \mathrm{C}$. This was confirmed for all nanoparticles obtained in temperature range $370390{ }^{\circ} \mathrm{C}$ which is close to those determined by other authors [45]. In addition, the samples obtained at the synthesis temperature of $180{ }^{\circ} \mathrm{C}$ exhibited better thermal stability due to the increase of the crystallinity degree detected in these samples. Fig. 5a shows the DSC TG results for sample III. The TG data plots the weight loss of the nanoparticles which has been found to take place in the temperature range of $305.2382 .2{ }^{\circ} \mathrm{C}$ with a total weight loss percentage of $29.8 \%$. It can be attributed to the decomposition of magnesium hydroxide, which is close to the theoretical weight loss of $30.8 \mathrm{wt} \%$ of pure magnesium hydroxide. For the DSC curve, an endothermic peak has been found at $378.5^{\circ} \mathrm{C}$. In addition, Fig. $5 \mathrm{~b}$ shows the XRD results obtained for the decomposition residue of sample III after TG DSC analyses. It can be seen that the peaks corresponding to (111), (200),
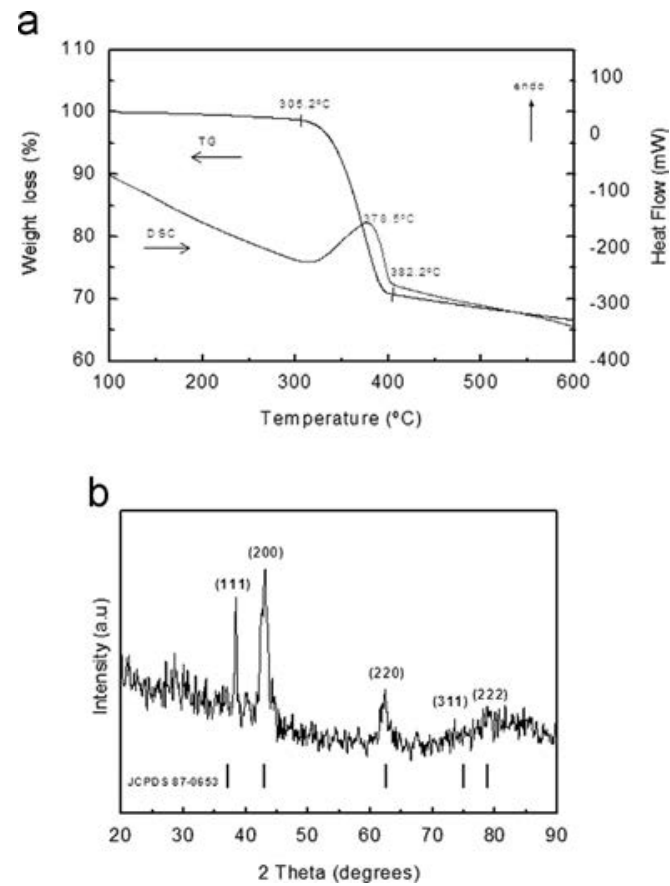

Fig. 5. (a) TG DSC curves of the thermal decomposition of sample III, heated in nitrogen $\left(\mathrm{N}_{2}\right)$ flow from 25 to $600{ }^{\circ} \mathrm{C}$. (b) XRD results obtained for the decomposition residue of the sample after TG DSC analyses. 
(220), (311) and (222) planes of the periclase phase ( $\mathrm{MgO}$, JCPDS 87-0653) with cubic symmetry indicate the $\mathrm{Mg}(\mathrm{OH})_{2}$ to $\mathrm{MgO}$ phase transformation associated with the presence of large amount defects as suggested by the diffractogram shape.

\section{Conclusions}

In this study, $\operatorname{Mg}(\mathrm{OH})_{2}$ nanoflakes with different morphologies were successfully synthesized via the hydrothermal method. The presented results show that the synthesis temperature and reaction time have a strong influence on the morphology, size particle, agglomeration level and crystallographic structures of the different nanocrystalline brucites obtained. It has been shown that the prolongation of reaction time improves the crystalline degree of magnesium hydroxide particles. It was also possible to detect a relevant increase of the crystallinity degree and a faster crystal growth with defined hexagonal morphologies in the samples obtained at $180{ }^{\circ} \mathrm{C}$. Consequently, from the above results, the hydrothermal method has proven its effectiveness as a simple process, is environment friendly and highly interesting to the large-scale production of these nanomaterials. In addition, magnesium hydroxide obtained shows a high thermal stability. For this reason, it can be considered as a promising inorganic flame retardant product.

\section{Acknowledgments}

This study has been supported by the Geomaterials Programme (S2009/MAT-1629) and the ESTRUMAT Programme (S2009/MAT-1585) and it has been carried out in the Department of Materials Science and Engineering and Chemical Engineering of the University Carlos III of Madrid, Spain. The authors are grateful to the National Center for Electron Microscopy (CNME) for its support with TEM. Their gratitude extends to the technician Cristina Moral of the University Carlos III of Madrid for her assistance in the SEM photographs and analyses.

\section{References}

[1] C. Janning, E. Willbold, C. Vogt, J. Nellesen, A. Meyer Lindenberg, H. Windhagen, F. Thorey, F. Witte, Magnesium hydroxide temporarily enhancing osteoblast activity and decreasing the osteoclast number in perimplant bone remodelling, Acta Biomater. 6 (2010) 18611868.

[2] F. Al Hazmi, A. Umar, G.N. Dar, A.A. Al Ghamdi, S.A. Al Sayari, A. Al Hajry, S.H. Kim, R.M. Al Tuwirqi, F. Alnowaiserb, F. El Tantawy, Microwave assisted rapid growth of $\mathrm{Mg}(\mathrm{OH})_{2}$ nanosheet networks for ethanol chemical sensor application, J. Alloys Compd. 519 (2012) 48 .

[3] L.S. Gomez Villalba, P. López Arce, R. Fort, Nucleation of $\mathrm{CaCO}_{3}$ polymorphs from a colloidal alcoholic solution of $\mathrm{Ca}(\mathrm{OH})_{2}$ nanocrystals exposed to low humidity conditions, Appl. Phys. A 106 (2011) 213217.

[4] D. Chelazzi, G. Poggi, Y. Jaidar, N. Tocaffondi, R. Giorgi, P. Baglioni, Hydroxide nanoparticles for cultural heritage: consolidation and protec tion of wall paintings and carbonate materials, J. Colloid Interface Sci. $392(2013) 4249$.

[5] L. Kumari, W.Z. Li, C.H. Vannoy, R.M. Leblanc, D.Z. Wang, Synthesis, characterization and optical properties of $\mathrm{Mg}(\mathrm{OH})_{2}$ micro /nanostructure and its conversion to $\mathrm{MgO}$, Ceram. Int. 35 (2009) 33553364.
[6] H.K. Bharadwaj, J. Y. Lee, X. Li, Z. Liu, T.C. Keener, Dissolution Kinetics of magnesium hydroxide for $\mathrm{CO}_{2}$ separation from coal fired power plants, J. Hazard. Mater. 250251 (2013) 292297.

[7] C. Dong, J. Cairney, Q. Sun, O.L. Maddan, G. He, Y. Deng, Investigation of $\mathrm{Mg}(\mathrm{OH})_{2}$ nanoparticles as an actibacterial agent, J. Nanopart. Res. 12 (2010) 21012109.

[8] C. Dong, D. Song, J. Cairney, O.L. Maddan, G. He, Y. Deng, Antibacterial study of $\mathrm{Mg}(\mathrm{OH})_{2}$ nanoplatelets, Mater. Res. Bull. 46 (2001) 576582 .

[9] C. Carrot, B. Olalla, R. Fulchiron, Relaxation of loose agglomerates of magnesium hydroxide in a polymer melt, Polymer 53 (24) (2012) 55605567.

[10] S. Ulutan, M. Gilbert, Mechanical properties of HDPE/magnesium hydroxide composites, J. Mater. Sci. 35 (9) (2000) 21152120.

[11] H. Ma, Z. Chen, Z. Mao, Controlled growth of magnesium hydroxide crystals and its effect on the high temperature properties of cotton/ magnesium hydroxide composites, Vacuum 95 (2013) 15.

[12] R. Giorgi, C. Bozzi, L. Deo, C. Gabbiani, B.W. Ninham, P. Baglioni, Nanoparticles of $\operatorname{Mg}(\mathrm{OH})_{2}$ : synthesis and application to paper conserva tion, Langmuir 21 (2005) 84958501.

[13] J. Fagerlund, R. Zevenhoven, An experimental study of $\operatorname{Mg}(\mathrm{OH})_{2}$ carbonation, Int. J. Greenh. Gas Control 5 (2011) 14061412

[14] Y. Zhang, M. Ma, X. Zhang, B. Zhang, B. Wang, R. Liu, Synthesis, characterization, and catalytic property of nanosized $\mathrm{MgO}$ flakes with different shapes, J. Alloys Compd. 590 (2014) 373379.

[15] S. Jakkula, V. Deshpande, Effect of $\mathrm{MgO}$ addition on the properties of $\mathrm{PbO} \mathrm{TiO}_{2} \quad \mathrm{~B}_{2} \mathrm{O}_{3}$ glass and glass ceramics, Ceram. Int. 39 (2013) 1518.

[16] Sikandar H. Tamboli, Aviraj Jatratkar, J.B. Yadav, Vijaya Puri, R.K. Puri, H.H. Cho, Ageing and vapor chopping effect on the properties of $\mathrm{MgO}$ thin films, J. Alloys Compd. 588 (2014) 321326.

[17] W. Fan, S. Sun, L. You, G. Cao, X. Song, W. Zhang, H. Yu, Solvothermal synthesis of $\mathrm{Mg}(\mathrm{OH})_{2}$ nanotubes using $\mathrm{Mg}_{10}(\mathrm{OH})_{18} \mathrm{Cl}_{2} \cdot 5 \mathrm{H}_{2} \mathrm{O}$ nanowires as precursors, J. Mater. Chem. 13 (2003) 30623065.

[18] W. Fan, S. Sun, X. Song, W. Zhang, H. Yu, X. Tan, G. Cao, Controlled synthesis of single crystalline $\mathrm{Mg}(\mathrm{OH})_{2}$ nanotubes and nanorods via a solvothermal process, J. Solid State Chem. 177 (7) (2004) 23292338.

[19] X. Li, C. Ma, J. Zhao, Z. Li, S. Xu, Y. Liu, Preparation of magnesium hydroxide nanoplates using a bubbling setup, Powder Technol. 198 (2010) 292297.

[20] G.W. Beall, E. S.M. Duraia, F. E. Tantawy, F. A. Hazmi, A.A. Al Ghamdi, Rapid fabrication of nanostructured magnesium hydroxide and hydromagne site via microwave assisted technique, Powder Technol. 234 (2012) 2631.

[21] P.S. Das, A. Dey, A.K. Mandal, N. Dey, N. Dey, A.K. Mukhopadhyay, Synthesis of $\mathrm{Mg}(\mathrm{OH})_{2}$ micro/nano flowers at room temperature, J. Adv. Ceram. 2 (2013) 173179.

[22] X. F. Wu, G. S. Hu, B. B. Wang, Y. F. Yang, Synthesis and character ization of superfine magnesium hydroxide with monodispersity, J. Cryst. Growth 310 (2008) 457461.

[23] H. Yan, X. H. Zhang, J. M. Wu, L. Q. Wei, X. G. Liu, B. S. Xu, The use of $\mathrm{CTAB}$ to improve the crystallinity and dispersibility of ultrafine magnesium hydroxide by hydrothermal route, Powder Technol. 188 (2008) 128132.

[24] M. Láska, J. Valtýni, P. Fellner, Influence of $\mathrm{pH}$ on the crystal size distribution of $\mathrm{Mg}(\mathrm{OH})_{2}$ prepared by the hydration of $\mathrm{MgO}$, Cryst. Res. Technol. 28 (1993) 931936.

[25] M. Sutcu, S. Akkurt, S. Okur, Influence of crystallographic orientation on hydration of $\mathrm{MgO}$ single crystals, Ceram. Int. 35 (2009) 25712576.

[26] H. y. Qian, M. Deng, S. m. Zhang, L. 1. Xu, Synthesis of superfine Mg $(\mathrm{OH})_{2}$ particles by magnesite, Mater. Sci. Eng. A 445446 (2007) 600603.

[27] C. Henrist, J. P. Mathieu, C. Vogels, A. Rulmont, R. Cloots, Morpho logical study of magnesium hydroxide nanoparticles precipitated in dilute aqueous solution, J. Cryst. Growth. 249 (2003) 321330.

[28] H. Dong, Z. Du, Y. Zhao, D. Zhou, Preparation of surface modified nano $\mathrm{Mg}(\mathrm{OH})_{2}$ via precipitation method, Powder Technol. 198 (2010) 325329. 
[29] G. Song, S. Ma, G. Tang, X. Wang, Ultrasonic assisted synthesis of hydrophobic magnesium hydroxide nanoparticles, Colloid Surf. A 364 (2010) 99104.

[30] Q. Wang, C. Li, M. Guo, L. Sun, C. Hu, Hydrothermal synthesis of hexagonal magnesium hydroxide nanoflakes, Mater. Res. Bull. 51 (2014) 3539.

[31] Q.L. Wu, L. Xiang, Y. Jin, Influence of $\mathrm{CaCl}_{2}$ on the hydrothermal modification of $\mathrm{Mg}(\mathrm{OH})_{2}$, Powder Technol. 165 (2006) 100104.

[32] J. Chen, L. Lin, Y. Song, L. Shao, Influence of KOH on the hydrothermal modification of $\mathrm{Mg}(\mathrm{OH})_{2}$ crystals, J. Cryst. Growth 311 (8) (2009) 24052408.

[33] D. Jin, X. Gu, X. Yu, G. Ding, H. Zhu, K. Yao, Hydrothermal synthesis and characterization of hexagonal $\mathrm{Mg}(\mathrm{OH})_{2}$ nano flake as a flame retardant, Mater. Chem. Phys. 112 (2008) 962965.

[34] A. Khorsand Zak, W.H. Abd. Majid, M. Ebrahimizadeh Abrishami, Ramin Yousefi, R. Parvizi, Synthesis, magnetic properties and $\mathrm{X}$ ray analysis of $\mathrm{Zn}_{0.97} \times{ }_{0.03} \mathrm{O}$ nanoparticles $(X=\mathrm{Mn}$, Ni and $\mathrm{Co})$ using Scherrer and size strain plots methods, Solid State Sci. 14 (2012) 488494.

[35] Q.L. Wu, L. Xiang, Y. Jin, Influence of $\mathrm{CaCl}_{2}$ on the hydrothermal modification of $\mathrm{Mg}(\mathrm{OH})_{2}$, Powder Technol. 165 (2006) 100104.

[36] L. Xiang, Y.C. Jin, Y. Jin, Hydrothermal formation of dispersive $\mathrm{Mg}(\mathrm{OH})_{2}$ particles in $\mathrm{NaOH}$ solution, Trans. Nonferrous Metals Soc. China 14 (2004) 116120.
[37] Y. Lv, Z. Zhang, Y. Lai, J. Lie, Y. Liu, Formation mechanism for planes (011) and (001) oriented $\mathrm{Mg}(\mathrm{OH})_{2}$ films electrodeposited on $\mathrm{SnO}_{2}$ coating glass, Cryst. Eng. Comm. 13 (2011) 38483851.

[38] P. Wang, C. Li, H. Gong, H. Wang, J. Liu, Morphology and growth mechanism of magnesium hydroxide nanoparticles via a simple wet precipitation method, Ceram. Int. 37 (2011) 33653370.

[39] D. Chen, L. Zhu, H. Zhang, K. Xu, M. Chen, Magnesium hydroxide nanoparticles with controlled morphologies via wet coprecipitation, Mater. Chem. Phys. 109 (2008) 224229.

[40] S.A. Morin, A. Forticaux, M.J. Bierman, S. Jin, Screw dislocation driven growth of two dimensional nanoplates, Nano Lett. 11 (2011) 44494455.

[41] D. Beruto, L. Barco, A.W. Searcy, G. Spinolo, Characterization of the porous $\mathrm{CaO}$ particles formed by decomposition of $\mathrm{Ca}(\mathrm{CO})_{3}$ and $\mathrm{Ca}(\mathrm{OH})_{2}$ in vacuum, J. Am. Ceram. Soc. 63 (1980) 439443.

[42] J.F. Goodman, The decomposition of magnesium hydroxide in an electron microscope, Proc. R. Soc. A 247 (1958) 346352.

[43] M.C. Ball, H.F.W. Taylor, The dehydration of brucite, Mineral. Mag. 32 (1961) 754766

[44] P.A. Van Anken, F. Langenhorst, Nanocrystalline, porous periclase aggregates as product of brucite dehydration, Eur. J. Mineral. 13 (2001) 329341.

[45] X. Wang, H. Pang, W. Chen, Y. Lin, G. Ning, Controllable fabrication of high purity $\mathrm{Mg}(\mathrm{OH})_{2}$ nanoneedles via direct transformation of natural brucite, Mater. Lett. 120 (2014) 6972. 